\title{
Farklı Çevrelerde Yetiştirilen Bazı Arpa Genotiplerinin Fiziksel ve Kimyasal Kalite Özelliklerinin Belirlenmesi
}

\author{
Determination of Physical and Chemical Quality Traits of Some Barley Genotypes \\ Grown in Different Environments
}

\section{Seydi AYDOĞAN ${ }^{1}$}

Mehmet ŞAHIN' ${ }^{1}$

Aysun GÖÇMEN AKÇACIK ${ }^{1}$

Sümeyra HAMZAOĞLU ${ }^{1}$

Berat DEMIR $^{1}$

İbrahim KARA ${ }^{1}$

${ }^{1}$ Bahri Dağdaş Uluslararası Tarımsal

Araştırma Enstitüsü Müdürlüğü- Konya

\section{*Sorumlu yazar:}

Seydi AYDOĞAN

seydiaydogan@yahoo.com

\section{ORCID (Yazar Sirasına göre):}

iD 0000-0003-0472-1211, iD 0000-0003-2446-

5227, iD 0000-0002-8209-0796, iD 0000-

0002-0572-3801, iD 0000-0001-6102-2527,

(iD 0000-0002-4097-5094

Gönderilme Tarihi:

24 Kasım 2020

Kabul Tarihi

17 Mart 2020

Destekleyen Kurum:

Bahri Dağdaş Uluslararası Tarımsal Araştırma Enst.

\section{ÖZET}

Bu çalışma 24 arpa genotipi ile (19 hat ve 5 standart çeşit) 20152016 yetiştirme sezonunda tesadüf blokları deneme desenine göre 2 tekerrürlü olarak yağışa dayalı şartlarda Konya-Gözlü ve Eskişehir lokasyonlarında yürütülmüştür. Bazı fiziksel ve kimyasal kalite özellikleri (bin tane ağırlığı, hektolitre ağırlığı, protein, beta glukan, ADF, NDF ve selüloz oranları, elek üstü (\% $2.8,2.5$ ve $2.5+2.8)$ ve elek altı $(\%<2.2)$ değerleri incelenmiştir. Kalite özelliklerine genotip ve çevre etkisinin belirlenmesi amaçlanmıştır. İncelenen kalite özelliklerinin iki lokasyon ortalamasına göre değer aralıkları; bin tane ağırlı̆̆ı 38.17-46.06 $\mathrm{g}$, hektolitre ağırlı̆̆ $57.34-64.31 \mathrm{~kg}$, elek analizi (\% 2.5+2.8) $\%$ 52.94-83.46, elek alt1 $(\%<2.2) \%$ 2.51-20.95, protein oranı $\% 10.22-11.70$, beta glukan oranı $\%$ 4.08-5.93, ADF \% 6.24-6.74, NDF \% 19.59-25.36 ve selüloz oranı \% 5.95-6.64 olarak belirlenmiştir. İncelenen özellikler yönüyle genotipler ve lokasyonlar arasında önemli farklılıklar tespit edilmiştir. Eskişehir lokasyonunda bin tane ağırlığı, hektolitre ağırlığı, elek üstü değerleri, beta glukan ve NDF değerleri bakımından yüksek değerler elde edilmiştir.

Anahtar Sözcükler: Arpa, lokasyon, beta glukan, ADF ve NDF

\section{ABSTRACT}

This study was carried out with 24 barley genotypes (19 lines and 5 standard varieties) in Konya-Gözlü and Eskişehir locations in rainfed conditions according to randomized block designed with two replications in the 2015-2016 growing season. Some 
physical and chemical quality traits (thousand kernel weight, test weight, protein, beta glucan, ADF, NDF, and cellulose ratios, over-screen $(2.8,2.5$ and $2.5+2.8 \%)$ and under-screen $(<2.2 \%)$ values were examined. It is aimed to determine the genotype and environmental impact on quality traits. According to the two location averages of the examined quality traits value ranges; thousand kernel weight 38.17-46.06 g, test weight 57.34-64.31 kg, sieve analysis $(2.5 \%+2.8) 52.94-83.46 \%$, under the sieve (<2.2\%) 2.51-20.95\%, protein ratio 10.22-11.70\%, beta glucan ratio 4.08-5.93 \%, ADF 6.24-6.74 \%, NDF 19.59$25.36 \%$ and cellulose ratio 5.95-6.64\% determined as. Significant differences were identified between genotypes and locations in terms of examined traits. High values were obtained in Eskişehir location in terms of thousand kernel weight, test weight, over-screen values, beta glucan and NDF values.

Keywords: Barley, location, beta glukan, ADF and NDF

\section{GİRIŞ}

Arpa; hayvan yemi, malt endüstrisi ve insan ek gıdası olarak dünya tahıl kaynakları arasında önemli bir yere sahiptir. Geniş adaptasyon yeteneği ile Dünyada ve ülkemizde geniş bir coğrafyada yetişme alanı bulmaktadır. Türkiye'nin uygun çevre koşullarına sahip olmasından dolayı arpa yetiştiriciliği buğdaydan sonra ikinci sırada yer almaktadır. Türkiye'de, 2.7 milyon hektar alanda yıllık 6.7 milyon ton üretime ve ortalama $248.1 \mathrm{~kg} / \mathrm{da}$ verime sahiptir (TUİK, 2018). Dünyada ekimi yapılan arpanın \% 65'i hayvan yemi, \% 33'ü malt yapımı, \% 2'si gıda endüstrisinde kullanılmaktadır. Ülkemizde tüketimin \% 90'1 hayvan yemi, kalan kısmı maltlık olarak ve gida endüstrisinde kullanılmaktadır (Anonim 2020). Besin maddeleri kompozisyonu yönünden tahıl taneleri içinde en değişkenlik gösteren ve tüm hayvanlar tarafından sevilerek tüketilen arpanın, özellikle ruminantlar için uygun olduğu belirtilmektedir (Bolat ve ark., 1996). Arpa tanesindeki yüksek sindirilebilir lif ve $\beta$-glukan oranı ile insan beslenmesinde önem kazanmaya başlamıştır. Bazı ülkelerde arpa unu, buğday ununa katkı maddesi olarak kullanılmaktadır (Sipahi ve ark. 2010). Arpa tanesi, içerdiği yaklaşık \% 67 karbonhidrat, \% 10 protein, \% 2 yağ, \% 5 selüloz ve kalsiyum, fosfor, potasyum gibi mineraller, A, E ve B vitaminleri ile hayvan beslenmesinde önemli bir yere sahiptir. Genetik farklılıkların arpanın kimyasal içeriğini etkilediği ve farklı genotiplerin mineral madde içeriğinin farklı olduğu daha önce yapılmış olan çalışmalarda belirtilmektedir (Guo ve ark. 2003). Betaglukan en yaygın olarak bitkilerde selüloz yapıda, tahıllar içinde özellikle yulafta ve arpada, ekmek mayasının hücre duvarında, bazı küf, mantar ve bakterilerde bulunmaktadır. Bulundukları yere bağlı olarak farklı bağ konfigürasyonuna sahip olmaktadır (Volman ve ark., 2008). Artan hayvan yemi ve endüstriyel kullanım taleplerinin karşılanabilmesi için farklı bölgelere uyumlu, yüksek verim ve kaliteye sahip yeni arpa çeşitleri geliştirilmesini amaçlayan sslah programları devreye sokulmuştur. Arpa geniş alanlarda üretilebilmesi ve üreticilerimizin önemli bir gelir kaynağı olmasından dolayı üretimin ve verimin artırılması için uyum sağlayacak bölgelerin belirlenmesi önem kazanmaktadır. Farklı çeşitler değişen çevre koşullarına farklı tepkiler göstermektedir (Sirat ve ark., 2012). Bu çalışmada bazı arpa genotiplerinin yağışa bağlı koşullarda farklı çevrelerde bazı fiziksel ve kimyasal kalite özelliklerinin belirlenmesi kalite yönünden ümitvar olan hatların tespit edilerek yeni arpa çeşidi geliştirme çalışmalarına katkıda bulunulması amaçlanmıştır.

\section{MATERYAL VE YÖNTEM}

$\mathrm{Bu}$ çalışma 2015-2016 yetiştirme sezonunda KonyaGözlü ve Eskişehir lokasyonlarındaki kuru arpa bölge verim denemelerinde yer alan arpa genotiplerinin kalite çalışmaları tesadüf blokları deneme deseninde 2 tekerrürlü olarak yürütülmüştür. Araştırmada 19 hat ve 5 çeşit (Karatay 94, Tarm 92, Larende, İnce 04 ve Akar) kullanılmıştır. Denemelerin ekimi parsel mibzeriyle her parselde 6 sira ve $550 \mathrm{adet} / \mathrm{m}^{2}$ tohum olacak şekilde yapılmıştır. Parsel boyutları $1.2 \mathrm{~m} \mathrm{x} 7 \mathrm{~m}$ olarak ayarlanmışve her parsel arasında $35 \mathrm{~cm}$ mesafe bırakılmıştır. Ekimle birlikte her parsele 2.7 $\mathrm{kg} / \mathrm{da} \mathrm{N}$ ve $6.9 \mathrm{~kg} / \mathrm{da} \mathrm{P}_{2} \mathrm{O}_{5}$ ve üst gübre olarak da $4 \mathrm{~kg} / \mathrm{da}$ $\mathrm{N}$ verilmiştir. Yetiştirme döneminde Konya lokasyonunda yağış oranı $241.8 \mathrm{~mm}$, Eskişehir lokasyonunda $336 \mathrm{~mm}$ olmuştur. Arpa tanesinde bazı kalite özellikleri (bin tane ağırlığı, hektolitre ağırlığı, elek üstü analizi \% (2.5, 2.8), \% 2.2 elek altı, protein, beta glukan, ADF, NDF ve selüloz oranları) incelenmiştir. Protein oranı AOAC 992.23 Leco FP 528 cihazı ile belirlenmiş (Anonymous, 2009), beta glukan AACC 32-23, selüloz, ADF ve NDF Near infrared reflektans spektroskopi (NIR) cihazı ile AACC 32-10 metoduna göre (Anonymous, 2000), bin tane ağırlığı, 
hektolitre ağırlığı ve elek analizi \% (2.2, 2.5, 2.8) (Elgün ve ark., 2001)'e göre belirlenmiştir. Elde edilen verilerin varyans analizleri JMP istatistik programıla (Anonymous, 2014) yapılmış, önemli çıkan ortalamalar gruplandırılarak kalite özellikleri yönüyle iyi olan genotipler belirlenmiş, kalite özelliklerine ait değerlerin seleksiyonda kullanılması sağlanmıştır.

\section{BULGULAR VE TARTIŞMA}

İncelenen on bir özellikte genotip, lokasyon, genotip*lokasyon interaksiyonlarına ilişkin kareler ortalamaları iki çevre üzerinde birleştirilmiş varyans analizi sonuçları Çizelge 1'de verilmiştir. ortalaması $47.00 \mathrm{~g}$, hatların ortalaması $47.83 \mathrm{~g}$ olarak tespit edilmiştir. Hatlar içinde en yüksek bin tane ağırlı̆̆ 53.88 g ile 4'nolu hat, en düşük değer ise 41.16 g ile 2'nolu hatta tespit edilmiştir. Eskişehir lokasyonunda standart çeşitlerin bin tane ağırllı̆̆ ortalaması $46.17 \mathrm{~g}$ olup, çeşitler içinde en yüksek değer $50.68 \mathrm{~g}$ ile Larende çeşidinde, en düşük değer ise $42.56 \mathrm{~g}$ ile Tarm 92 çeşidinde elde edilmiştir. Eskişehir lokasyonunda hatların bin tane ağırlığının Konya-Gözlü lokasyonunda olduğu gibi standart çeşitler ve deneme ortalaması üzerinde değerler elde edilmiştir. Eskişehir lokasyonu Konya-Gözlü lokasyonuna göre bin tane ağırlığı deneme ortalaması bakımından $10.60 \mathrm{~g}$ daha fazla değer elde edilmiştir. Her iki lokasyon ortalamasında en yüksek

Çizelge 1. İncelenen Arpa Genotiplerinin Kalite Özelliklerine İlişkin Birleştirilmiş Varyans Analizi Sonuçları

\begin{tabular}{|c|c|c|c|c|c|c|c|}
\hline Kaynak & SD & Bin tane (g) & Hektolitre (kg) & $2.8(\%)$ & $2.5(\%)$ & Elek altı (\%) & Elek $(2.5+2.8)$ \\
\hline Lokasyon & 1 & $2982.7366^{* *}$ & $830.72667 * *$ & $42310.384 * *$ & $106.7871 *$ & $3947.5350 * *$ & $38165.958 * *$ \\
\hline Genotip & 23 & $537.0529 * *$ & $211.97388 * *$ & $17578.158 * *$ & $5241.3344 * *$ & $2120.5817^{* *}$ & $8756.973 * *$ \\
\hline Tekerrür & 1 & 0.962 & 0.27307 & 10.567 & 29.029 & 31.5104 & 74.624 \\
\hline Lokasyon*Genotip & 23 & $308.6455^{* *}$ & $100.92143 * *$ & $9899.019 * *$ & $9512.7662 * *$ & $1865.8300 * *$ & $4993.237 * *$ \\
\hline Hata & 47 & 88.233 & 36.4475 & 423.924 & 905.647 & 587.6044 & 2063.786 \\
\hline Kaynak & SD & Protein $(\%)$ & $\operatorname{ADF}(\%)$ & NDF (\%) & Selüloz (\%) & \multicolumn{2}{|c|}{ Beta Glukan (\%) } \\
\hline Lokasyon & 1 & $543.59202 * *$ & $22.863776^{* *}$ & $905.83450 * *$ & $43.969801 * *$ & \multicolumn{2}{|c|}{$11.746004 * *$} \\
\hline Genotip & 23 & $13.51720 * *$ & $2.383566 * *$ & $162.89810 * *$ & $1.939299 * *$ & \multicolumn{2}{|c|}{$19.116233 * *$} \\
\hline Tekerrür & 1 & 0.0495 & 0.099459 & 0.31396 & 0.006176 & \multicolumn{2}{|c|}{0.001067} \\
\hline Lokasyon*Genotip & 23 & $14.84368^{* *}$ & $3.741449 * *$ & $66.34662 * *$ & $1.760474 * *$ & \multicolumn{2}{|c|}{$3.668296 * *$} \\
\hline Hata & 47 & 5.1876 & 0.949691 & 19.2629 & 0.932174 & \multicolumn{2}{|c|}{4.088733} \\
\hline
\end{tabular}

\section{Bin Tane A}

İncelenen arpa genotiplerinin bin tane ağırlığı değerlerinin lokasyonlardaki değişimleri Çizelge 2'te verilmiştir. KonyaGözlü lokasyonunda arpa genotiplerinin bin tane ağırlığı 32.22-39.86 g arasında değişmiş, deneme ortalaması 36.40 $\mathrm{g}$, hatların ortalaması $36.13 \mathrm{~g}$ olarak belirlenmiştir. Hatlar içinde en yüksek değer 3'nolu hat $39.68 \mathrm{~g}$ ve en düşük değer ise 7'nolu hatta $32.22 \mathrm{~g}$ olarak tespit edilmiştir. Standart çeşitlerin bin tane ağırlı̆̆ı ortalaması 36.67 g olup, çeşitler içinde en yüksek değer 39.86 g ile Tarm 92, en düşük değer ise $33.54 \mathrm{~g}$ ile İnce 04 çeşidinde elde edilmiştir. Kızılgeçi ve ark. 2019, Diyarbakır ve Mardin koşullarında 2011-2012 yılınlarında 7 genotipin bin tane ağıllı̆̆ $42.21-45.02 \mathrm{~g}$ arasında değiştiğini tespit etmişlerdir. Eskişehir lokasyonunda genotiplerinin bin tane ağırlığı 41.16-53.88 g arasında değişmiş, deneme bin tane ağırlığı 4, 9 ve 3' nolu hatlarda, standart çeşitler de ise Akar ve Larende de tespit edilmiştir (Çizelge 2). Bin tane ağırlığında lokasyonlar arasında görülen farklılık yetiştirme döneminde ki toplam yağış oranı ve genotiplerin performanslarından kaynaklanmaktadır. Aydoğan ve ark. (2011), 2006-2007 yetiştirme döneminde yaptıkları bir çalışmada Konya-merkez ve Çumra lokasyonlarında ortalama bin tane ağırlığını sırasıyla $36.72 \mathrm{~g}$ ve $37.82 \mathrm{~g}$, birleştirilmiş lokasyon ortalamasını ise $37.21 \mathrm{~g}$ olarak tespit etmişlerdir.

\section{Hektolitre A ğırlığı}

İncelenen arpa genotiplerinin hektolitre ağırllğı KonyaGözlü lokasyonunda 53.19-61.92 kg arasında değişmiş, deneme ortalaması $58.26 \mathrm{~kg}$, hatların ortalamas $58.68 \mathrm{~kg}$ olarak belirlenmiştir (Çizelge 2). Hatlar içinde en yüksek 
hektolitre ağırlı̆̆1 61.92 kg ile 2'nolu hat, en düşük değer ise $53.19 \mathrm{~kg}$ ile 7'nolu hatta belirlenmiştir. Standart çeşitlerin hektolitre ağırllı̆ı ortalaması $57.85 \mathrm{~kg}$ olup, standart çeşitler içinde en yüksek değer $59.52 \mathrm{~kg}$ ile Tarm 92 çeşidinde elde edilmiştir. Konya-Gözlü lokasyonunda yer alan hatların hektolitre ağırlığı standart çeşitler ve deneme ortalaması üzerinde değerler elde edilmiştir. Eskişehir lokasyonunda genotiplerin hektolitre ağıllı̆̆ $58.42-66.71 \mathrm{~kg}$ arasında değişmiş, deneme ortalaması $64.30 \mathrm{~kg}$, hatların ortalaması $64.41 \mathrm{~kg}$ olarak belirlenmiştir. Hatlar içinde en yüksek hektolitre ağırlığ $66.71 \mathrm{~kg}$ ile 2 ve 22 'nolu hatlar, en düşük değer ise $58.42 \mathrm{~kg}$ ile 12 'nolu hatta tespit edilmiştir. Standart çeşitlerin hektolitre ağırlığı ortalaması $64.19 \mathrm{~kg}$ olup, standart çeşitler içinde en yüksek değer $65.84 \mathrm{~kg}$ ile Tarm 92 çeşidinde belirlenmiştir. Çöken, (2015), Isparta ekolojik koşullarında 12 adet arpa çeşitlerinin hektolitre ağırlı̆̆ının 66.20 ile $76.36 \mathrm{~kg}$ arasında değiştiğini tespit etmişlerdir. Eskişehir lokasyonunda hatların hektolitre ağırlığ 1 ortalaması, standart çeşitler ve deneme ortalaması üzerinde olmuş, Konya-Gözlü lokasyonuna göre deneme ortalaması bakımından $6.04 \mathrm{~kg}$ daha yüksek değer elde edilmiştir. Her iki lokasyon ortalamasını değerlendirdiğimizde hatlar içinde en yüksek hektolitre ağırlığı $64.31 \mathrm{~kg}$ ile 2'nolu hatta, standart çeşitler içinde ise Tarm 92 çeşidinde elde edilmiştir (Çizelge 2). Kızılgeçi ve ark. (2019), Diyarbakır lokasyonunda arpa da hektolitre ağırlığının $58.44-68.07 \mathrm{~kg}$, Mardin lokasyonunda 59.21-65.40 kg değerleri aralığında değiştiğini tespit etmişlerdir. Aydoğan ve ark. (2016), 20102014 yıllarına ait arpa hat ve standart çeşitlerinin bazı kalite özelliklerinin değerlendirildiği bir çalışmalarında 2548 genotipte yıllar itibarı ile ortalama hektolitre ağırlığının $51.27 \mathrm{~kg}$ ile $77.10 \mathrm{~kg}$ arasında değiştiğini tespit etmişler, bu değişimin en önemli sebeplerinin genotip, iklim ve lokasyon farklıklarından kaynaklandığını belirtmişlerdir.

\section{Elek Analizi}

Arpada elek analizleri tanenin dolgunluk ve zayıf olmasını belirttiği gibi tanenin homojen olup olmadığı hakkında da fikir vermektedir. İncelenen arpa genotiplerinin KonyaGözlü lokasyonunda \% 2.8 elek üstü değerleri \% 2.3123.63 arasında değişmiş, deneme ortalamasının \% 11.33, hatların ortalamasının \% 13.57 olduğu tespit edilmiştir (Çizelge 3). Eskişehir lokasyonunda arpa genotiplerinin \% 2.8 elek üstü elek üstü değerleri \% 23.36-83.94 arasında

Çizelge 2. Arpa Genotiplerinin Bin Tane ve Hektolitre Ağırlıklarına ait Ortalama Değerler

\begin{tabular}{|c|c|c|c|c|c|c|}
\hline \multirow[b]{2}{*}{ Genotipler } & \multicolumn{3}{|c|}{ Bin Tane Ağırlığı (g) } & \multicolumn{3}{|c|}{ Hektolitre Ağırlığı (kg) } \\
\hline & Konya (Gözlü) & Eskişehir & Ortalama & Konya (Gözlü) & Eskişehir & Ortalama \\
\hline 1 & 37.62 & 45.80 & 41.71 & 58.92 & 64.96 & 61.94 \\
\hline 2 & 36.74 & 41.16 & 38.95 & 61.92 & 66.71 & 64.31 \\
\hline 3 & 39.68 & 52.00 & 45.84 & 58.21 & 62.78 & 60.49 \\
\hline 4 & 38.24 & 53.88 & 46.06 & 59.95 & 64.96 & 62.46 \\
\hline 6 & 39.06 & 52.64 & 45.85 & 58.86 & 66.27 & 62.57 \\
\hline 7 & 32.22 & 44.12 & 38.17 & 53.19 & 61.48 & 57.34 \\
\hline 8 & 36.20 & 48.60 & 42.40 & 58.86 & 64.96 & 61.91 \\
\hline 9 & 38.79 & 53.00 & 45.90 & 58.98 & 66.27 & 62.63 \\
\hline 11 & 34.18 & 42.20 & 38.19 & 58.43 & 65.40 & 61.91 \\
\hline 12 & 33.78 & 43.68 & 38.73 & 59.73 & 58.42 & 59.08 \\
\hline 13 & 33.74 & 45.44 & 39.59 & 61.04 & 65.40 & 63.22 \\
\hline 14 & 33.34 & 48.12 & 40.73 & 57.56 & 63.22 & 60.39 \\
\hline 16 & 39.60 & 46.04 & 42.82 & 58.86 & 63.22 & 61.04 \\
\hline 17 & 36.02 & 49.92 & 42.97 & 57.99 & 62.35 & 60.17 \\
\hline 18 & 36.08 & 46.56 & 41.32 & 60.61 & 65.40 & 63.00 \\
\hline 19 & 35.82 & 47.60 & 41.71 & 58.65 & 66.27 & 62.46 \\
\hline 21 & 36.54 & 50.64 & 43.59 & 56.68 & 64.53 & 60.61 \\
\hline 22 & 32.72 & 49.52 & 41.12 & 57.77 & 66.71 & 62.24 \\
\hline Hatların Ort. & 36.13 & 47.83 & 41.98 & 58.68 & 64.41 & 61.54 \\
\hline Karatay 94 & 37.04 & 43.40 & 40.22 & 57.56 & 62.78 & 60.17 \\
\hline Tarm 92 & 39.86 & 42.56 & 41.21 & 59.52 & 65.84 & 62.68 \\
\hline Larende & 35.40 & 50.68 & 43.04 & 56.25 & 63.66 & 59.95 \\
\hline İnce 04 & 33.54 & 46.72 & 40.13 & 57.56 & 64.96 & 61.26 \\
\hline Ayranci & 35.78 & 45.71 & 40.74 & 56.90 & 64.24 & 60.57 \\
\hline Akar & 38.40 & 47.96 & 43.18 & 59.30 & 63.66 & 61.48 \\
\hline Standart Ort. & 36.67 & 46.17 & 41.42 & 57.85 & 64.19 & 61.02 \\
\hline Genel Ortalama & 36.40 & 47.00 & 41.70 & 58.26 & 64.30 & 61.28 \\
\hline $\mathbf{D K}_{(\%)}$ & 5.35 & 1.79 & 3.34 & 2.06 & 4.35 & 2.45 \\
\hline $\mathbf{A O ̈ F _ { ( 0 . 0 5 ) }}$ & 3.99 & 0.17 & 1.96 & 2.49 & 0.57 & 1.24 \\
\hline
\end{tabular}


değişmiş, deneme ortalaması \% 47.53, standartların ortalaması \% 33.73 ve hatların ortalaması ise \% 61.33 olarak tespit edilmiştir. Her iki lokasyonda da denemede yer alan hatların ortalama elek üstü değerleri standart çeşitler ve deneme ortalaması üzerinde olmuştur. KonyaGözlü lokasyonunda genotiplerin \% 2.5 elek üstü değerleri \% 22.20-46.98 arasında değişmiş, deneme ortalaması $\%$ 35.27, hatların ortalaması ise \% 38.53 olarak tespit edilmiştir. Eskişehir lokasyonunda genotiplerinin \% 2.5 elek üstü değerleri \% 13.00-67.88 arasında değişmiş, deneme ortalaması \% 39.32, hatların ortalaması \% 30.26 olarak tespit edilmiştir. Konya-Gözlü lokasyonunda hatların \% 2.5 elek üstü değerleri ortalaması, standart çeşitler ve deneme ortalaması üzerinde olmuştur (Çizelge 3). Genotiplerin \% $(2.5+2.8)$ elek üstü değerleri KonyaGözlü lokasyonunda \% 24.51-69.58 arasında değişmiş, deneme ortalaması \% 46.59, hatların ortalaması \% 52.10 olarak tespit edilmiştir (Çizelge 4). Eskişehir lokasyonunda genotiplerinin \% $(2.5+2.8)$ elek üstü değerleri \% 72.4498.04 arasında değişmiş, deneme ortalaması \% 86.85, hatların ortalaması \% 91.59 olarak tespit edilmiştir. Denemede yer alan hatlar ve standart çeşitlerin lokasyon bazında \% $(2.5+2.8)$ elek üstü deneme ortalamaları Eskişehir lokasyonunda Konya-Gözlü lokasyonuna göre \% 40.26 daha yüksek olmuştur (Çizelge 4). Eskişehir lokasyonunda elek üstü değerlerinin yüksek olmasının en önemli sebebinin bölgede alınan yağış oranının yüksek olmasından kaynaklandığı düşünülmektedir. Her iki lokasyonda da hatların \% $(2.5+2.8)$ elek üstü ortalama değerinin, standartlar ve deneme ortalaması üzerinde olduğu tespit edilmiştir(Çizelge 4). Aydoğan ve ark. (2013), farklı iki lokasyonda yaptıkları bir çalışmada ortalama (\%

Çizelge 3. Arpa Genotiplerinin \% 2.8 ve \% 2.5 Elek Üstü Ortalamalarına ait Değerler

\begin{tabular}{|c|c|c|c|c|c|c|}
\hline \multirow[b]{2}{*}{ Genotipler } & \multicolumn{3}{|c|}{$\%(2.8)$ Elek üstü } & \multicolumn{3}{|c|}{$\%$ (2.5) Elek üstü } \\
\hline & Konya (Gözlï) & Eskişehir & Ortalama & Konya (Gözlü) & Eskişehir & Ortalama \\
\hline 1 & 7.60 & 23.36 & 15.48 & 40.14 & 57.20 & 48.67 \\
\hline 2 & 22.76 & 76.40 & 49.58 & 38.50 & 20.72 & 29.61 \\
\hline 3 & 23.63 & 79.28 & 51.46 & 45.95 & 16.96 & 31.46 \\
\hline 4 & 21.33 & 83.56 & 52.45 & 46.78 & 14.48 & 30.63 \\
\hline 6 & 22.54 & 83.94 & 53.24 & 45.35 & 13.00 & 29.18 \\
\hline 7 & 2.31 & 39.04 & 20.68 & 22.20 & 42.32 & 32.26 \\
\hline 8 & 8.16 & 52.58 & 30.37 & 42.72 & 38.16 & 40.44 \\
\hline 9 & 23.20 & 83.94 & 53.57 & 44.50 & 13.28 & 28.89 \\
\hline 11 & 4.94 & 25.36 & 15.15 & 34.26 & 52.10 & 43.18 \\
\hline 12 & 11.01 & 60.56 & 35.79 & 41.61 & 30.02 & 35.82 \\
\hline 13 & 18.92 & 75.06 & 46.99 & 43.03 & 21.28 & 32.16 \\
\hline 14 & 12.34 & 71.98 & 42.16 & 31.95 & 24.46 & 28.21 \\
\hline 16 & 17.61 & 36.94 & 27.28 & 39.29 & 43.14 & 41.22 \\
\hline 17 & 13.81 & 69.60 & 41.71 & 36.50 & 25.30 & 30.90 \\
\hline 18 & 17.17 & 63.56 & 40.37 & 46.98 & 32.24 & 39.61 \\
\hline 19 & 6.82 & 51.00 & 28.91 & 32.63 & 40.08 & 36.36 \\
\hline 21 & 4.65 & 63.30 & 33.98 & 28.17 & 28.88 & 28.53 \\
\hline 22 & 5.43 & 64.56 & 35.00 & 33.01 & 31.06 & 32.04 \\
\hline Hatların Ort. & 13.57 & 61.33 & 37.45 & 38.53 & 30.26 & 34.40 \\
\hline Karatay 94 & 13.29 & 29.62 & 21.46 & 32.05 & 43.56 & 37.81 \\
\hline Tarm 92 & 5.91 & 24.22 & 15.07 & 43.32 & 48.22 & 45.77 \\
\hline Larende & 2.27 & 14.32 & 8.30 & 17.94 & 66.74 & 42.34 \\
\hline İnce 04 & 6.86 & 58.66 & 32.76 & 36.44 & 32.98 & 34.71 \\
\hline Ayrancı & 3.41 & 64.00 & 33.70 & 18.41 & 30.92 & 24.66 \\
\hline Akar & 22.75 & 11.58 & 17.17 & 43.87 & 67.88 & 55.88 \\
\hline Standart Ort. & 9.08 & 33.73 & 21.41 & 32.01 & 48.38 & 40.19 \\
\hline Genel Ortalama & 11.33 & 47.53 & 29.43 & 35.27 & 39.32 & 37.29 \\
\hline $\mathbf{D K}_{(\%)}$ & 3.40 & 2.28 & 7.21 & 5.09 & 2.87 & 8.12 \\
\hline $\mathbf{A O ̈ F}_{(0.05)}$ & 8.71 & 3.70 & 4.26 & 8.71 & 6.21 & 6.23 \\
\hline
\end{tabular}


Çizelge 4. Arpa Genotiplerinin \% (2.8+2.5) ve \% 2.2 Elek Altı Ortalamalarına ait Değerler

\begin{tabular}{|c|c|c|c|c|c|c|}
\hline \multirow[t]{2}{*}{ Genotipler } & \multicolumn{3}{|c|}{$\%(2.5+2.8)$ Elek üstü } & \multicolumn{3}{|c|}{ Elek altı \% $(<2.2)$} \\
\hline & Konya (Gözlï) & Eskişehir & Ortalama & Konya (Gözlü) & Eskişehir & Ortalama \\
\hline 1 & 47.74 & 80.56 & 64.15 & 14.05 & 3.04 & 8.54 \\
\hline 2 & 61.26 & 97.12 & 79.19 & 7.43 & 0.76 & 4.09 \\
\hline 3 & 69.58 & 96.24 & 82.91 & 4.65 & 0.38 & 2.51 \\
\hline 4 & 68.11 & 98.04 & 83.08 & 6.31 & 0.10 & 3.20 \\
\hline 6 & 67.89 & 96.94 & 82.42 & 6.03 & 0.56 & 3.29 \\
\hline 7 & 24.51 & 81.36 & 52.94 & 26.66 & 5.18 & 15.9 \\
\hline 8 & 50.88 & 90.74 & 70.81 & 12.31 & 1.42 & 6.86 \\
\hline 9 & 67.70 & 97.22 & 82.46 & 7.70 & 0.30 & 4.00 \\
\hline 11 & 39.20 & 77.46 & 58.33 & 16.69 & 4.04 & 10.36 \\
\hline 12 & 52.62 & 90.58 & 71.60 & 9.37 & 4.72 & 7.04 \\
\hline 13 & 61.95 & 96.34 & 79.15 & 6.96 & 0.46 & 3.71 \\
\hline 14 & 44.29 & 96.44 & 70.37 & 13.47 & 0.22 & 6.84 \\
\hline 16 & 56.90 & 80.08 & 68.49 & 12.26 & 3.02 & 7.64 \\
\hline 17 & 50.31 & 94.90 & 72.61 & 13.69 & 1.22 & 7.45 \\
\hline 18 & 64.15 & 95.80 & 79.98 & 8.16 & 0.38 & 4.27 \\
\hline 19 & 39.45 & 91.08 & 65.27 & 18.65 & 1.06 & 9.85 \\
\hline 21 & 32.82 & 92.18 & 62.50 & 24.94 & 1.46 & 13.20 \\
\hline 22 & 38.44 & 95.62 & 67.03 & 19.54 & 0.38 & 9.96 \\
\hline Hatların Ort. & 52.10 & 91.59 & 71.85 & 12.72 & 1.59 & 7.15 \\
\hline Karatay 94 & 45.34 & 73.18 & 59.26 & 18.87 & 6.14 & 12.50 \\
\hline Tarm 92 & 49.23 & 72.44 & 60.84 & 11.24 & 6.42 & 8.83 \\
\hline Larende & 20.21 & 81.06 & 50.64 & 39.94 & 1.96 & 20.95 \\
\hline İnce 04 & 43.30 & 91.64 & 67.47 & 15.53 & 0.56 & 8.045 \\
\hline Ayrancı & 21.82 & 94.91 & 58.37 & 34.07 & 0.40 & 17.23 \\
\hline Akar & 66.62 & 79.46 & 73.04 & 6.04 & 2.58 & 4.31 \\
\hline Standart Ort. & 41.09 & 82.12 & 61.60 & 20.95 & 3.01 & 11.98 \\
\hline Genel Ortalama & 46.59 & 86.85 & 66.72 & 16.83 & 2.30 & 9.57 \\
\hline DK ${ }_{(\%)}$ & 6.84 & 2.24 & 7.50 & 5.24 & 3.03 & 4.12 \\
\hline AÖF $F_{(0.05)}$ & 9.15 & 4.12 & 9.40 & 5.15 & 4.12 & 5.20 \\
\hline
\end{tabular}

$2.5+2.8)$ elek üstü değerini $2009-2010$ yılında $\% 40.83$, 2010-2011 yılında ise \% 60.53 olarak belirlemişler, iki yıl ve dört çevrede en yüksek değerin Karatay-94 ve İnce-04 çeşitlerinde elde edildiğini tespit etmişlerdir. İncelenen arpa genotiplerinin elek altı \% (<2.2) değeri Konya-Gözlü lokasyonunda \% 4.65-39.94 arasında değişmiş, deneme ortalaması \% 16.83, hatların ortalaması \% 12.72 olarak belirlenmiştir. En düşük değer hatlar içinde \% 4.65 ile 3'nolu hatta, standart çeşitler içinde ise \% 6.04 ile Akar çeşidinde elde edilmiştir (Çizelge 4). Eskişehir lokasyonunda genotiplerinin elek altı değerleri \% 0.10-6.42 arasında değişmiş, deneme ortalaması \% 2.30, hatların ortalaması $\% 1.59$ olarak tespit edilmiştir. En düşük değer \% 0.10 ile 4'nolu hatta, standart çeşitler içinde ise \% 0.40 ile Ayrancı çeşidinde belirlenmiştir. Bu değerin düşük olması tane yapısının iri ve homojen olduğunun bir göstergesi olarak kabul edilmektedir. Lokasyon bazında elek altı \% (<2.2) ortalama değerleri bakımından Eskişehir lokasyonunda Konya-Gözlü lokasyonuna göre \% 14.53 daha düşük değer belirlenmiştir. Her iki lokasyonda da elek altı değeri bakımından hatların, standartlar ve deneme ortalamasına göre düşük değer verdiği tespit edilmiştir (Çizelge 4).

\section{Protein Oranı}

$\mathrm{Bu}$ araştırmada farklı çevrelere göre arpa genotiplerinin protein oranı değerlerinin değişimleri Çizelge 5 'da verilmiştir. Konya-Gözlü lokasyonunda protein oranı \% 12.03-14.39 arasında değişmiş, deneme ortalaması \% 13.23, hatların ortalaması \% 13.15 olarak belirlenmiştir. Hatlar içinde en yüksek protein oranı \% 14.39 ile 22' nolu hatta, en düşük değer ise \% 12.03 ile 17'nolu hatta belirlenmiştir. Standart çeşitlerin protein ortalaması \% 13.30 olup, standart çeşitler içinde en yüksek değer \% 14.12 ile Tarm 92 çeşidinde tespit edilmiştir. Aydoğan 
ve ark. (2016), 2010-2014 yıllarını kapsayan bir çalışmalarında hat ve standart çeşitlerin protein oranının \% 8.36-15.94 arasında değiştiğini, bu değişimin genotiplerin genetik özelliği ve lokasyonların farklı özelliklerinden kaynaklandığını bildirmişlerdir. Arpa tanesi, yaklaşık \% 7.5-15 protein, \% 75 oranında da hazm olunabilir besin maddesi içeriği ile çok iyi bir besin kaynağıdır (Akkaya ve Akten 1986). Eskişehir lokasyonunda genotiplerinin protein oranı \% 8.72-10.83 arasında değişmiş, deneme ortalaması $\% 9.95$, hatların ortalaması \% 9.91 olarak tespit edilmiştir. Hatlar içinde en yüksek protein oranı \% 10.83 ile 17 'nolu hatta, en düşük değer ise \% 8.72 ile 21 'nolu hatta elde edilmiştir. Denemede yer alan standart çeşitlerin protein ortalaması \% 9.98 olup, standart çeşitler içinde en yüksek değer \% 10.78 ile Tarm 92 çeşidinde tespit edilmiştir (Çizelge 5). Protein oranı bakımından Eskişehir lokasyonunda Konya-Gözlü lokasyonuna göre deneme ortalaması bakımından \% 3.28 daha düşük değer elde edilmiştir. Eskişehir lokasyonunda genotiplerin bin tane ağırlığı, hektolitre ağırlığg ve elek üstü değerlerinin yüksek olmasına bağlı olarak tane protein oranı değerleri düşüş göstermiştir. Her iki lokasyon ortalamasına göre hatlar içinde en yüksek protein oranı \% 11.59 ile 8'nolu hatta, standart çeşitler içinde en yüksek değer Tarm 92 çeşidinde tespit edilmiştir. Aydoğan ve ark. (2011), iki yıl iki çevrede yaptıkları bir çalışmada arpa genotiplerin protein oranının yıllar ve çevrelerdeki değişimlerini incelemişler, 2006-2007 yılı ortalama protein oranını \% 11.82, Çumra ve Konyamerkezdeki ortalama değerleri sırasıyla \% 12.83 ve 10.81 , 2007-2008 yılı ortalama protein oranını \% 11.31, Çumra ve Konya-merkezdeki ortalama değerleri sırasıyla \% 9.25 ve 13.37 olarak tespit etmişlerdir.

\section{Beta Glukan}

Beta glukan yulafta aleuron tabakasının altında, arpada ise çoğunlukla endospermde yoğunlaşmış durumdadır. Yulaf ve arpada beta 1-3, 1-4 bağlarının durumu çözünebilirlik ve viskozitede rol oynayan en önemli etkenlerdir. Beta

Çizelge 5. Arpa Genotiplerinin Protein ve Beta Glukan Oranlarına ait Ortalama Değerler

\begin{tabular}{|c|c|c|c|c|c|c|}
\hline \multirow{2}{*}{ Genotipler } & \multicolumn{3}{|c|}{ Protein Oranu $(\%)$} & \multicolumn{3}{|c|}{ Beta Glukan Oranu (\%) } \\
\hline & Konya(Gözlü) & Eskişehir & Ortalama & Konya (Gözlü) & Eskişehir & Ortalama \\
\hline 1 & 13.65 & 9.62 & 10.88 & 4.90 & 5.47 & 5.19 \\
\hline 2 & 12.18 & 9.75 & 10.22 & 3.85 & 5.17 & 4.51 \\
\hline 3 & 13.08 & 9.62 & 10.60 & 4.31 & 5.82 & 5.06 \\
\hline 4 & 13.51 & 9.55 & 10.78 & 4.46 & 4.43 & 4.44 \\
\hline 6 & 13.20 & 9.71 & 10.71 & 4.58 & 5.40 & 4.99 \\
\hline 7 & 13.26 & 10.20 & 10.98 & 4.11 & 4.59 & 4.35 \\
\hline 8 & 13.90 & 10.77 & 11.59 & 4.73 & 5.78 & 5.25 \\
\hline 9 & 13.46 & 10.27 & 11.11 & 4.34 & 5.33 & 4.83 \\
\hline 11 & 13.29 & 10.36 & 11.08 & 4.42 & 4.94 & 4.68 \\
\hline 12 & 12.34 & 10.34 & 10.59 & 3.95 & 4.21 & 4.08 \\
\hline 13 & 12.37 & 9.72 & 10.30 & 4.31 & 5.02 & 4.67 \\
\hline 14 & 13.48 & 10.03 & 11.01 & 4.23 & 4.80 & 4.51 \\
\hline 16 & 12.84 & 10.13 & 10.74 & 4.53 & 5.17 & 4.85 \\
\hline 17 & 12.03 & 10.83 & 10.68 & 3.71 & 4.99 & 4.35 \\
\hline 18 & 13.19 & 10.16 & 10.92 & 3.85 & 4.56 & 4.20 \\
\hline 19 & 13.46 & 9.11 & 10.54 & 4.38 & 4.97 & 4.68 \\
\hline 21 & 13.14 & 8.72 & 10.18 & 4.34 & 4.88 & 4.61 \\
\hline 22 & 14.39 & 9.53 & 11.21 & 5.13 & 5.99 & 5.56 \\
\hline Hatların. Ort & 13.15 & 9.91 & 10.78 & 4.34 & 5.08 & 4.71 \\
\hline Karatay 94 & 13.67 & 10.17 & 11.17 & 4.83 & 5.33 & 5.08 \\
\hline Tarm 92 & 14.12 & 10.78 & 11.70 & 4.62 & 4.88 & 4.75 \\
\hline Larende & 13.02 & 9.39 & 10.45 & 5.36 & 6.51 & 5.93 \\
\hline İnce 04 & 13.18 & 9.45 & 10.56 & 4.30 & 5.02 & 4.66 \\
\hline Ayranci & 13.02 & 10.39 & 10.85 & 5.26 & 5.13 & 5.19 \\
\hline Akar & 13.01 & 9.73 & 10.62 & 5.14 & 5.97 & 5.55 \\
\hline Standart Ort. & 13.30 & 9.98 & 10.89 & 4.92 & 5.47 & 5.19 \\
\hline Genel Ortalama & 13.23 & 9.95 & 10.84 & 4.63 & 5.28 & 4.95 \\
\hline $\mathbf{D K}_{(\%)}$ & 3.56 & 3.35 & 3.30 & 4.40 & 4.16 & 6.21 \\
\hline $\mathrm{AÖF}_{(0.05)}$ & 0.96 & 0.36 & 0.46 & 0.84 & 0.52 & 0.42 \\
\hline
\end{tabular}


glukanın viskozitesi ile molekül ağırlığı arasında pozitif bir korelasyon olup, elde edildikleri kaynağa göre ağırlıkları farklılık göstermektedir (Ahmad ve ark., 2012). İncelenen arpa genotiplerinin beta glukan oranı Konya-Gözlü lokasyonunda \% 3.71-5.36 arasında değişmiş, deneme ortalaması \% 4.63, hatların ortalaması \% 4.34 olarak belirlenmiştir. Hatlar içinde en yüksek beta glukan oranı \% 5.13 ile 22'nolu hatta, en düşük değer ise \% 3.71 ile 17'nolu hatta tespit edilmiştir. Denemede yer alan standart çeşitlerin beta glukan ortalaması \% 4.92 olup, en yüksek değer \% 5.36 ile Larende çeşidinde, en düşük değer ise \% 4.30 ile İnce 04 çeşidinde elde edilmiştir. Eskişehir lokasyonunda genotiplerinin beta glukan oranı \% 4.21-6.51 arasında değişmiş, deneme ortalaması \% 5.28, hatların ortalaması \% 5.08 olarak tespit edilmiştir (Çizelge 5). Hatlar içinde en yüksek beta glukan oranı \% 5.99 ile 22'nolu hatta, en düşük değer ise \% 4.21 ile 12 'nolu hatta belirlenmiştir. Standart çeşitlerin beta glukan oranı ortalaması \% 5.47 olup, en yüksek değer \% 6.51 ile Larende çeşidinde, en düşük değer ise \% 4.88 ile Tarm 92 çeşidinde elde edilmiştir. Larende çeşidinde her iki lokasyonda da yüksek beta glukan değeri elde edilmiştir. Eskişehir lokasyonunda deneme ortalaması Konya-Gözlü lokasyonuna göre \% 0.65 daha düşük olmuştur. Her iki lokasyon ortalamasını değerlendirdiğimizde en yüksek beta glukan oranı hatlar içinde \% 5.56 ile 22' nolu hatta, standart çeşitler içinde ise \% 5.93 ile Larende çeşidinde elde edilmiştir (Çizelge 5). Yalçın ve ark. (2007)'nın 16 kavuzsuz arpa ve 1 adet kavuzlu arpa çeşiti (Tarm-92) ile 3 farklı lokasyonda (Sincan, Haymana, Yenimahalle) yaptıkları çalışmada, $\beta$-glukan oranı Tarm-92 çeşitinde lokasyonlara göre sırasıyla $\% 5.07, \% 4.80, \% 4.58$ olmuş; kavuzsuz arpaların $\beta$-glukan oranı ise lokasyonlara göre sirasiyla \% 3.88 - \% 5.10, \% 4.13 - \% 5.08, \% 3.73 - \% 4.90 arasında değiştiğini tespit etmişlerdir.

\section{ADF Oranı}

İncelenen arpa genotiplerinin lokasyonlara göre $\mathrm{ADF}$ oranları Çizelge 6'de verilmiş olup, Konya-Gözlü lokasyonunda genotiplerin ADF oranı \% 6.68-7.50 arasında değişmiş, deneme ortalaması \% 7.04, hatların ortalaması \% 7.00 olarak belirlenmiştir. Hatlar içinde en yüksek ADF oranı \% 7.29 ile 17'nolu hatta, en düşük değer ise \% 6.68 ile 11 'nolu hatta tespit edilmiştir. Denemede yer alan standart çeşitlerin ADF oranı ortalaması \% 7.07 olup, standart çeşitler içinde en yüksek değer \% 7.50 ile Ayrancı' çeşidinde, en düşük değer ise $\% 6.75$ ile Tarm 92 çeşidinde elde edilmiştir. Eskişehir lokasyonunda genotiplerin ADF oranı \% 5.49-6.57 arasında değişmiş, deneme ortalaması $\% 5.97$, hatların ortalaması $\% 6.12$ olarak tespit edilmiştir. Hatlar içinde en yüksek ADF oranı \% 6.57 ile 12'nolu hatta, en düşük değer ise \% 5.51 ile 13 ve 22'nolu hatta belirlenmiştir. Standart çeşitlerin ADF oranı ortalaması \% 5.81 olup, standart çeşitler içinde en yüksek değer \% 6.17 ile Karatay 94 çeşidinde, en düşük değer ise \% 5.49 ile Akar çeşidinde belirlenmiştir. Eskişehir lokasyonunda hatların ADF oranı ortalaması, standart çeşitler ve deneme ortalaması üstünde değere sahipken Konya-Gözlü lokasyonunda düşük olmuştur. Eskişehir lokasyonu ADF deneme ortalaması, Konya-Gözlü lokasyonu ADF deneme ortalamasından \% 1.07 daha düşük olmuştur. Her iki lokasyon ortalamasında en yüksek ADF oranı hatlar içinde \% 6.74 ile 12' nolu hatta, standart çeşitler içinde ise \% 6.66 ile Karatay 94 çeşidinde tespit edilmiştir (Çizelge 6). Alkan ve Kandemir (2015), yapmış oldukları bir çalışmada Tokak yerel arpa çeşidinden seçilmiş saf hatların ADF oranlarının \% 6.53-9.07 arasında değiştiğini tespit etmişlerdir. Tekce ve Gül (2014), NDF ve ADF'nin ruminatlarda tükürük salgısını teşvik ettiğini, rumen pH'sının normal sınırlar içinde kalmasını sağladığını; NDF ve ADF miktarlarının, birçok metabolik hastalığın önlenmesi açısından önemli olduğunu da belirtmişlerdir.

\section{NDF Oranı}

İncelenen arpa genotiplerinin NDF oranı Konya-Gözlü lokasyonunda \% 16.81-21.68 arasında değişmiş, deneme ortalaması \% 18.37, hatların ortalaması \% 18.47 olarak belirlenmiştir. Hatlar içinde en yüksek NDF oranı \% 21.68 ile 2'nolu hatta, en düşük değer ise \% 16.93 ile 22'nolu hatta belirlenmiştir. Denemede yer alan standart çeşitlerin NDF oranı ortalaması \% 18.26 olup, standart çeşitler içinde en yüksek değer \% 20.09 ile İnce 04, en düşük değer ise \% 16.81 ile Larende çeşidinde belirlenmiştir(Çizelge 6). Konya-Gözlü lokasyonunda hatların NDF oranı ortalaması, standart çeşitler ve deneme ortalamasının üstünde değere sahip olmuştur. Fife ve ark. (2008), arpa tanesinde NDF oranının \% 19.9-24.5 arasında değiştiğini, Aldemir ve Karslı (2012), yaptıkları bir çalışmada arpa çeşitlerinin ortalama NDF değerinin \% 35.87 olduğunu belirlemişlerdir. Eskişehir lokasyonunda genotiplerin NDF 
Çizelge 6. Arpa Genotiplerinin ADF, NDF ve Selüloz Oranlarına ait Ortalama Değerler

\begin{tabular}{|c|c|c|c|c|c|c|c|c|c|}
\hline \multirow{2}{*}{ Genotipler } & \multicolumn{3}{|c|}{$\operatorname{ADF}(\%)$} & \multicolumn{3}{|c|}{ NDF $(\%)$} & \multicolumn{3}{|c|}{ Selüloz (\%) } \\
\hline & Konya(Gözlü) & Eskişehir & Ortalama & Konya(Gözlü) & Eskişehir & Ortalama & Konya(Gözlü) & Eskişehir & Ortalama \\
\hline 1 & 7.03 & 6.00 & 6.52 & 18.80 & 24.25 & 21.53 & 7.06 & 5.36 & 6.21 \\
\hline 2 & 6.83 & 6.44 & 6.63 & 21.68 & 29.03 & 25.36 & 6.82 & 5.78 & 6.30 \\
\hline 3 & 7.11 & 6.30 & 6.70 & 18.75 & 26.99 & 22.87 & 7.03 & 5.66 & 6.34 \\
\hline 4 & 6.93 & 6.52 & 6.72 & 19.47 & 24.42 & 21.94 & 6.82 & 5.45 & 6.14 \\
\hline 6 & 7.00 & 6.21 & 6.60 & 18.60 & 29.31 & 23.96 & 6.86 & 5.80 & 6.33 \\
\hline 7 & 7.00 & 6.31 & 6.65 & 17.58 & 25.39 & 21.49 & 6.92 & 5.81 & 6.37 \\
\hline 8 & 7.13 & 5.91 & 6.52 & 17.37 & 21.98 & 19.67 & 7.03 & 5.59 & 6.31 \\
\hline 9 & 6.95 & 6.02 & 6.48 & 18.71 & 24.76 & 21.73 & 6.90 & 5.59 & 6.24 \\
\hline 11 & 6.68 & 6.32 & 6.50 & 19.87 & 22.69 & 21.28 & 6.95 & 5.73 & 6.34 \\
\hline 12 & 6.90 & 6.57 & 6.74 & 19.48 & 23.76 & 21.62 & 6.94 & 5.87 & 6.41 \\
\hline 13 & 7.01 & 5.51 & 6.26 & 19.59 & 25.08 & 22.34 & 6.71 & 5.19 & 5.95 \\
\hline 14 & 7.18 & 5.98 & 6.58 & 17.00 & 22.45 & 19.72 & 7.12 & 5.76 & 6.44 \\
\hline 16 & 7.19 & 6.02 & 6.60 & 18.01 & 22.49 & 20.25 & 6.92 & 5.79 & 6.36 \\
\hline 17 & 7.29 & 6.02 & 6.66 & 17.90 & 24.19 & 21.04 & 6.78 & 5.95 & 6.36 \\
\hline 18 & 6.85 & 6.52 & 6.69 & 17.91 & 23.10 & 20.50 & 7.03 & 5.67 & 6.35 \\
\hline 19 & 6.93 & 6.03 & 6.48 & 17.54 & 25.04 & 21.29 & 7.22 & 5.78 & 6.50 \\
\hline 21 & 7.14 & 6.00 & 6.57 & 17.31 & 26.14 & 21.73 & 7.14 & 5.39 & 6.26 \\
\hline 22 & 6.98 & 5.51 & 6.24 & 16.93 & 24.49 & 20.71 & 7.51 & 5.64 & 6.57 \\
\hline Hatların Ort. & 7.00 & 6.12 & 6.56 & 18.47 & 24.75 & 21.61 & 6.98 & 5.66 & 6.32 \\
\hline Karatay 94 & 7.14 & 6.17 & 6.66 & 18.78 & 23.94 & 21.36 & 7.26 & 5.77 & 6.52 \\
\hline Tarm 92 & 6.75 & 5.79 & 6.27 & 17.02 & 23.39 & 20.21 & 7.29 & 6.00 & 6.64 \\
\hline Larende & 7.12 & 6.01 & 6.57 & 16.81 & 22.38 & 19.59 & 7.26 & 5.57 & 6.41 \\
\hline İnce 04 & 6.99 & 5.64 & 6.31 & 20.09 & 25.22 & 22.66 & 7.06 & 5.42 & 6.24 \\
\hline Ayranci & 7.50 & 5.79 & 6.64 & 18.15 & 24.02 & 21.08 & 7.17 & 5.55 & 6.36 \\
\hline Akar & 6.94 & 5.49 & 6.21 & 18.74 & 24.99 & 21.86 & 6.63 & 5.75 & 6.19 \\
\hline Standart Ort. & 7.07 & 5.81 & 6.44 & 18.26 & 23.99 & 21.13 & 7.11 & 5.68 & 6.39 \\
\hline Genel Ort. & 7.04 & 5.97 & 6.50 & 18.37 & 24.37 & 21.37 & 7.05 & 5.67 & 6.36 \\
\hline $\mathbf{D K} \mathbf{K}_{(\%)}$ & 6.54 & 2.93 & 2.23 & 2.29 & 4.93 & 3.52 & 2.42 & 1.59 & 2.33 \\
\hline AÖF(0.05) & 0.35 & 0.23 & 0.20 & 1.81 & 0.45 & 0.90 & 0.35 & 0.19 & 0.18 \\
\hline
\end{tabular}

oranı \% 21.98-29.31 arasında değişmiş, deneme ortalaması $\%$ 24.37, hatların ortalaması \% 24.75 olarak belirlenmiştir. Hatlar içinde en yüksek NDF oranı \% 29.31 ile 6'nolu hatta, en düşük değer ise \% 21.98 ile 8'nolu hatta tespit edilmiştir. Denemede yer alan standart çeşitlerin NDF oranı ortalaması \% 23.99 olup, standart çeşitler içinde en yüksek değer \% 25.22 ile İnce 04 çeşidinde, en düşük değer ise \% 22.38 ile Larende çeşidinde elde edilmiştir. Eskişehir lokasyonununda hatların ortalama NDF oranı standart çeşitler ve deneme ortalaması üstünde değere sahip olmuştur. Eskişehir lokasyonu NDF deneme ortalaması Konya-Gözlü lokasyonundan \% 6 daha düşük olmuştur. Her iki lokasyon ortalamasına göre hatlar içinde en yüksek
NDF oranı \% 25.36 ile 2' nolu hatta, standart çeşitler içinde \% 22.66 ile İnce 04 çeşidinde tespit edilmiştir(Çizelge 6). Alkan ve Kandemir (2015), yaptıkları bir çalışmada NDF oranının \% 19.77-26.61 arasında değiştiğini tespit etmişlerdir. Yapılan birçok çalışmada NDF oranındaki fazla artışın besicilikte yem tüketiminin sınırlanmasına sebep olduğunu belirlemişlerdir.

\section{Selüloz Oranı}

Tanede selüloz oranı tanenin sindirilebilirliği açısından oldukça önemli olup incelenen genotiplerin selüloz oranı Çizelge 6'de verilmiştir. Selüloz oranı Konya-Gözlü lokasyonunda \% 6.63-7.51 arasında değişmiş, deneme 
ortalaması \% 7.05, hatların ortalaması \% 6.98 olarak belirlenmiştir. Hatlar içinde en yüksek selüloz oranı \% 7.51 ile 22 'nolu hatta, en düşük değer ise \% 6.71 ile 13 'nolu hatta elde edilmiştir. Denemede yer alan standart çeşitlerin selüloz oranı ortalaması \% 7.11 olup, standart çeşitler içinde en düşük değer \% 6.63 ile Akar, en yüksek değer ise \% 7.29 ile Tarm 92 çeşidinde elde edilmiştir. Eskişehir lokasyonunda genotiplerin selüloz oranı \% 5.19-6.00 arasında değişmiş, deneme ortalaması \% 5.67, hatların ortalaması \% 5.66 olarak belirlenmiştir. Hatlar içinde en düşük selüloz oranı \% 5.19 ile 13'nolu hatta, en yüksek değer ise \% 5.95 ile 17’nolu hatta elde edilmiş olup, yemlik arpalarda bu oranının düşük olması arzu edilmektedir. Denemede yer alan standart çeşitlerin selüloz oranı ortalaması \% 5.68 olup, standart çeşitler içinde en düşük değer \% 5.42 ile İnce 04 çeşidinde, en yüksek değer ise \% 6.00 ile Tarm 92 çeşidinde elde edilmiştir. Eskişehir lokasyonu selüloz oranı deneme ortalaması Konya-Gözlü lokasyonuna göre \% 1.38 daha düşük değere sahip olmuştur. Her iki lokasyon ortalamasına göre hatlar içinde en düşük selüloz oranı \% 5.95 ile 13' nolu hatta, standart çeşitler içinde \% 6.19 ile Akar çeşidinde belirlenmiştir(Çizelge 6). İki lokasyon ortalaması bakımından hatların selüloz oranı ortalamasının standart çeşitler ve deneme ortalamasının altında değer aldıkları belirlenmiştir.
İncelenen özelliklerin korelasyon katsayılarına göre Hektolitre ağırlığı ile; bin tane ağırlığı $\left(0.8063^{* *}\right)$, \% 2.8 elek üstü $\left(0.7419^{* *}\right)$, NDF oranı $\left(0.8305^{* *}\right)$, beta glukan $\left(0.4861^{* *}\right)$ arasında önemli pozitif ilişki, ADF oranı $\left(-0.7958^{* *}\right)$, protein oranı $\left(-0.8501^{* *}\right)$, selüloz oranı $\left(-0.8518^{* *}\right)$ arasında ise negatif ilişki belirlenmiştir. Protein oranı ile; \% 2.5 elek üstü $\left(0.0671^{*}\right)$, ADF oranı $\left(0.8402^{* *}\right)$, selüloz oranı $\left(0.9667^{* *}\right)$ arasında pozitif, bin tane ağırlığ $1\left(-0.8736^{* *}\right)$, hektolitre ağırlığ $1\left(-0.8501^{* *}\right), \%$ 2.8 elek üstü $\left(-0.7751^{* *}\right), \operatorname{NDF}$ oranı $\left(-0.9068^{* *}\right)$ ve beta glukan $\left(-0.5162^{* *}\right)$ arasında ise negatif ilişki belirlenmiştir. ADF oranı ile; elek altı $\%<2.2\left(0.6493^{* *}\right)$ ve selüloz oranı $\left(0.8626^{* *}\right)$ arasında pozitif, bin tane ağırlığı $\left(-0.7667^{* *}\right)$, $\% 2.8$ elek üstü $\left(-0.6274^{* *}\right)$, NDF oranı $\left(-0.778^{* *}\right)$ ile negatif ilişki tespit edilmiştir. NDF oranı ile; bin tane ağırlığı $\left(0.8031^{* *}\right)$, \% 2.8 elek üstü $\left(0.8186^{* *}\right)$ ve beta glukan oranı $\left(0.4703^{* *}\right)$ arasında pozitif, elek altı $\%<2.2$ $\left(-0.7033^{* *}\right)$, selüloz oranı $\left(-0.8761^{* *}\right)$ arasında negatif ilișki belirlenmiștir. Selüloz oranı ile; elek altı $\%<2.2$ $\left(0.7537^{* *}\right)$ arasında önemli pozitif ve \% 2.8 elek üstü $\left(-0.7873^{* *}\right)$ negatif ilişki belirlenmiştir. Beta glukan ile; bin tane ağırlığı $\left(0.5801^{* *}\right)$, hektolitre ağırlığ 1 (0.4861), \% 2.8 elek üstü $\left(0.297^{*}\right)$ arasında önemli pozitif, elek altı \%<2.2 $\left(-0.2682^{*}\right)$ ile negatif ilişki tespit edilmiştir. Bin tane ağırlığı ile; \% 2.8 elek üstü $\left(0.8163^{* *}\right)$ arasında pozitif, elek altı

Çizelge 7. İncelenen özellikler arasındaki korelasyon katsayıları

\begin{tabular}{|c|c|c|c|c|c|}
\hline Değișken & Bağımlı Değişken & Korelasyon & Değişken & Bağımlı Değișken & Korelasyon \\
\hline Hektolitre Ağr. & Bin tane Ağr. & $0.8063 * *$ & NDF Oranı & $\% 2.8$ üstü & $0.8186^{* *}$ \\
\hline$\% 2.8$ üstü & Bin tane Ağr. & $0.8163 * *$ & NDF Oran1 & Elek alt $1 \%<2.2$ & $-0.7033 * *$ \\
\hline \% 2.8 üstü & Hektolitre Ağr. & $0.7419 * *$ & NDF Oranı & Protein Oran 1 & $-0.9068 * *$ \\
\hline Elek alt $\%<2.2$ & Bin tane Ağr. & $-0.7312 * *$ & NDF Oranı & ADF Oran 1 & $-0.778 * *$ \\
\hline Elek altı $\%<2.2$ & Hektolitre Ağr. & $-0.8005^{* *}$ & Selüloz Oranı & Bin tane Ağr. & $-0.8724 * *$ \\
\hline Elek altı $\%<2.2$ & $\% 2.8$ üstü & $-0.7069 * *$ & Selüloz Oranı & Hektolitre Ağr. & $-0.8518^{* *}$ \\
\hline Elek altı $\%<2.2$ & $\% 2.5$ üstü & $-0.2281^{*}$ & Selüloz Oranı & $\% 2.8$ üstü & $-0.7873 * *$ \\
\hline Protein Oran 1 & Bin tane Ağr. & $-0.8736^{* *}$ & Selüloz Oranı & Elek alt $\%<2.2$ & $0.7537 * *$ \\
\hline Protein Oran 1 & Hektolitre Ağr. & $-0.8501 * *$ & Selüloz Oranı & Protein Oran 1 & $0.9667 * *$ \\
\hline Protein Oran 1 & $\% 2.8$ üstü & $-0.7751 * *$ & Selüloz Oranı & ADF Oran 1 & $0.8626^{* *}$ \\
\hline Protein Oran 1 & $\% 2.5$ üstü & $0.0671^{*}$ & Selüloz Oranı & NDF Oran 1 & $-0.8761 * *$ \\
\hline Protein Oran 1 & Elek alt $1 \%<2.2$ & $0.6954 * *$ & Beta Glukan Oranı & Bin tane Ağr. & $0.5801 * *$ \\
\hline ADF Oran 1 & Bin tane Ağr. & $-0.7667 * *$ & Beta Glukan Oranı & Hektolitre Ağr. & $0.4861 * *$ \\
\hline ADF Oran 1 & Hektolitre Ağr. & $-0.7958 * *$ & Beta Glukan Oranı & $\% 2.8$ üstü & $0.297 *$ \\
\hline ADF Oran 1 & $\% 2.8$ üstü & $-0.6274 * *$ & Beta Glukan Oranı & Elek alt $1 \%<2.2$ & $-0.2682 *$ \\
\hline ADF Oran 1 & Elek alt $1 \%<2.2$ & $0.6493 * *$ & Beta Glukan Oranı & Protein Oran1 & $-0.5162 * *$ \\
\hline ADF Oran 1 & Protein Oran 1 & $0.8402 * *$ & Beta Glukan Oranı & ADF Oran1 & $-0.5639 * *$ \\
\hline NDF Oran1 & Bin tane Ağr. & $0.8031 * *$ & Beta Glukan Oranı & NDF Oran 1 & $0.4703 * *$ \\
\hline NDF Oranı & Hektolitre Ağr. & $0.8305^{* *}$ & Beta Glukan Oranı & Seluloz Oranı & $-0.5113 * *$ \\
\hline
\end{tabular}


$\%<2.2\left(-0.7312^{* *}\right)$ ile negatif ilişki tespit edilmiştir. \% 2.8 elek üstü ile elek altı $\%<2.2\left(-0.7069^{* *}\right)$ negatif ilişki tespit edilmiştir. \% 2.5 üstü ile elek altı $\%<2.2\left(-0.2281^{*}\right)$ negatif ilişki tespit edilmiştir (Çizelge 7).

\section{SONUÇ}

$\mathrm{Bu}$ çalışmada kuru arpa bölge verim denemesinde yer alan arpa hat ve çeşitlerinin farklı lokasyonlardaki kalite özellikleri incelenmiş, genotip ve çevrenin kalite özellikleri üzerine etkilerinin önemli olduğu belirlenmiştir. Arpa da ve diğer bitkilerde ekolojik koşullara uygun çeşit seçimi oldukça önemli olup kullanım amacına uygun kalitede arpa çeşitlerinin tercih edilmesi önem taşımaktadır. İncelenen kalite özellikleri bakımından lokasyonlar içinde KonyaGözlü koşullarında \% 2.5 elek üstü değeri, \% 2.2 elek altı değeri, protein oranı, ADF ve selüloz oranı bakımından yüksek değerler belirlenmiştir. Eskişehir lokasyonunda ise bin tane ağırlığı, hektolitre ağırlığı, \% 2.8, \% (2.5+2.8) elek üstü, beta glukan ve NDF oranı bakımından yüksek değerler elde edilmiştir. Tane fiziksel özellikler bakımından Eskişehir lokasyonunda yüksek değerler alınmıştır, bunun en önemli sebebinin ise bölgede alınan yağış oranının yüksek olmasından kaynaklandığı düşünülmektedir. İki lokasyonun ortalamasına göre ise bin tane ağırlığı, \% $(2.5+2.8)$ elek üstü değerleri bakımından 4' nolu hat ve Akar çeşidinde, protein oranı ve beta glukan bakımından 8 ' nolu hat ve ADF bakımından 12'nolu hat yüksek değere sahip olmuştur. İncelenen korelasyon analizinde elek üstü değerleri arttıkça bin tane ve hektolitre ağırlıklarının ve beta glukan oranlarının arttığı, protein oranı arttıkça ADF ve selüloz oranında artış olduğu, elek üstü (\% 2.8) değeri, beta glukan ve NDF oranında azalma olmuştur. İncelenen kalite özellikleri yetiştirilen çevrelere göre değişim göstermekte, verim ve kalite özellikleri çevre koşullarından oldukça fazla etkilenmektedirler. Genotiplerin farklı çevre koşullarında yetiştirilerek kalite özellikleri bakımından değerlendirilmesi, üstün performans gösterenlerin tespit edilmesi arpa ıslah çalışmalarında ıslah materyalinin seleksiyonuna ve kaliteli çeşitlerin geliştirilmesine katkı sağlayacaktır.

\section{KAYNAKLAR}

Ahmad A, Anjum FM, Zahoor T, Nawaz H, Muhammad S, Dilshad R. 2012. Beta-Glucan: A Valuable Functional Ingredient in Foods. Critical Reviews in
Food Science and Nutrition, 52: 201-212.

Akkaya A., Akten Ş., 1986. Kırac koşullarda farklı gubre uygulamalarının bazı kışlık arpa ceşitlerinde kışa dayanıklılık ve dane veri ile bazı verim oğelerine etkisi. Doğa, Tr. Tar. Or. D., 10(2): 127-140.

Aldemir R, Karslı MA. 2012. Yaş şeker pancarı posası silajının arpa yerine kullanımının koyunlarda duodenuma geçen toplam protein üzerine etkisi: 1 . Besin madde sindirimi ve mikrobiyal protein sentezi. YYU Veteriner Fakültesi Dergisi, 23 (2):89-98.

Alkan RA, Kandemir N. 2015. Tokak yerel arpa çeşidi içinden seçilen safhatların bazı gıda, yem ve tarımsal özellikler bakımından varyasyonları. Tarla Bitkileri Merkez Araştırma Enstitüsü Dergisi, 24 (2):124139.

Anonim 2020. Miller Değirmenci. Değirmenci ve Bakliyat Teknolojileri ve Yan sanayi dergisi. Sayı 117. https:// www.millermagazine.com/dunya-arpa-pazari/.html.

Anonymous 2000. Approved Methods of The American Association of Cereal Chemist. USA.

Anonymous 2009. Approvedmethodologies.www. leco. com/ Resources/ApprovedMethods.

Anonymous 2014. JMP11 2014. JSL Syntax Reference. SAS Institute. ISBN:978-1-62959-560-3.

Aydoğan S., Şahin M, Göçmen Akçacık A., Ayrancı R. 2013. Bazı Arpa Çeşitlerinin Verim ve Kalite Özelliklerinin Belirlenmesi. Türkiye 10. Tarla Bitkileri Kongresi 67-72 Konya.

Aydoğan, S., Şahin, M., Göçmen Akçacık, A., Ayrancı, 2011. Konya Koşullarına Uygun Yüksek Verimli ve Kaliteli Arpa Genotiplerinin Belirlenmesi Selçuk Tarım ve Gıda Bilimleri Dergisi 25 (1): 10-16 Konya.

Aydoğan, S., Şahin, M., Göçmen Akçacık, A., Demir, B., Hamzaoğlu, S., Kara, İ. 2016. Yemlik Arpa Genotiplerinin Kalite Özellikleri Açısından Islah Programı Kapsamında Değerlendirilmesi Bahri Dağdaş Bitkisel Araştırma Dergisi 5 (2): 68-76, 2016

Bolat, D., Deniz, S., Baytok, E., Oğuz, M.N., Gül, M.1996. Merada beslenen kuzulara farklı düzeylerde Arpa verilmesinin besi performansı ve karkas özelliklerine etkisi. Türkiye 3. Çayır Mera ve Yem Bitkileri Kongresi 17-19 Haziran 1996, Erzurum, 98-106.

Çöken, İ. 2015. Isparta Ekolojik Koşullarında Bazı Arpa 
(Hordeum Vulgare L.) Çeşitlerinin Verim Ve Kalite Özelliklerinin Belirlenmesi. Süleyman Demirel Üniversitesi Fen Bilimleri Enstitüsü (Yüksek Lisans

Tezi)

Elgün, A., Türker, S., Bilgiçli, N. 2001. Tahıl ve Ürünlerinde Analitik Kalite Kontrolü. Selcuk Ün. Gıda Mühendisliği Bölümü Ders Notları. Konya Ticaret Borsası, Konya.

Fife, T.E., Szasz, J.I., Hunt, C.W., Ahola, J.A. 2008. Relationship between quality characteristics of barley grain and digestibility in feedlot steers. The Professional Animal Scientist, 24(6), 560-565.

Guo, T.R., Zhang G.P., Zhou M.X., Wu F.B., Chen J. X. 2003. Genotypic Difference in Plant Growth and Mineral Composition in Barley Under Aluminum Stres. Agricultural Sciences in China, 2 (5): 494501.

Kızılgeçi, F., Yıldırım, M., Akıncı, C., Albayrak, Ö. 2019. Arpada Tane Verimi ve Kalite Özellikleri Üzerine Genotip ve Çevrenin Etkileşimi. KSÜ Tarım ve Doğa Derg 22(3): 346-353, DOI:10.18016/ ksutarimdogavi.499013.

Sipahi H., Sayım İ., Ergun N., Cetin G., 2010. Maltlık kalitesi yuksek arpa (Hordeum vulgare L.) ceşitlerinin geliştirilmesi. (Biyoteknoloji iş paketi: İkiye katlanmış haploid bitkilerin uretilmesi). Tubitak Projeleri

Sirat, A., Sezer, İ., Mut, Z. 2012. Bazı Kışlık Arpa (Hordeum vulgare L.) Çeşitlerinin genotip x çevre interaksiyonları ve stabilitelerinin belirlenmesi. Güfbed/Gustij, 2(2): 68-75.

Tekce, E., Gül, M. 2014. Ruminant beslemede NDF ve ADF'nin önemi. Atatürk Üniversitesi Veteriner Bilimleri Dergisi, 9(1): 63-73.

TUİK 2018. Türkiye İstatistik Kurumu. www.tuik.gov.tr (Erişim tarihi : 20/09/2018)

Volman JJ, Ramakers JD, Plat J. 2008. Dietary Modulation of Immune Function by Beta-Glucans. Physiology \& Behavior, 94: 276-284.

Yalçın, E., Çelik, S., Akar, T., Sayim, I. ve Köksel, H. 2007. Effects of genotype and environment on b-glucan and dietary fiber contents of hull-less barleys grown in Turkey, Food Chemistry 101, 171-176. 